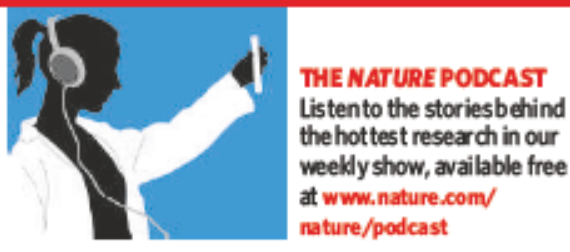

\title{
Far East lays plans to be stem-cell hotspot
}

Asia is aiming to secure its place as the world leader for cloning technologies. Many of the world's leading stemcell biologists and cloning specialists hail from countries such as South Korea and Jap an. And judging by the second Asian Reproductive Biotechnology conference, held from 2 to 7 November in Bangkok, Thailand, these pioneers are willing to share knowledge and techniques with scientists from less developed neighbours in the region, who are keen to enter the game.

"There is huge potential for Asian scientists here," says Woo Suk Hwang of Seoul National University in South Korea, who last year led the first team toderive stem cells from a cloned humanembryo.

Strong government supportand relatively relaxed ethical regulations are often cited as reasons for Asia's success in stem-cell biology, but Hwang singles out technical prowess as a critical factor. Many stem-cell biologists have noted that some labs in Europe and the
United States have struggled with skills already mastered by researchers in Asia, such as those needed to operate the micromanipulator devices used toremove nuclei from cells during the cloning process.

The researchers at the meeting, who numbered around 150 , saw a demonstration of one such technique from Teruhiko Wakayama of the RIKEN Center for Developmental Biology in Kobe, Japan, who in 1998 created the first cloned mouse. Biologists from Vietnam and Thailand were able to try extracting nuclei from egg cells with his piezoelectric device.

Many labs in Asia, in which even basics such as refrigerators can run short, cannot afford to experiment with such techniques, says Nguyen Van Thuan, who also works at the RIKEN Center. He presented one potential solution: a method for storing mouse sperm at room temperature for up to a week by adding salt to the bovine serum album in solution in

leaks. That vial is placed inside at least one other plastic container. This is held inside a polystyrene box containing dry ice, which itself lies inside a heavy cardboard box. Some of the packaging must pass tests such as freefall drops and has survived air crashes, says Plummer: "It's very, very safe."

Critics note that there is still a risk that the package could be lost or misdelivered, but Plummer says that is unlikely because the sender and recipient would know that the package is in transit. He adds that other select agents, including Ebola virus, are frequently sent in this way. If the virus did escape, it is unclear how serious the consequences would be (see 'How bad would it be if the virus escaped?').

Kuhn argues that the more places and people work with the virus, the greater the chance that it will escape or be stolen. He says that there should be an international agreement that restricts work on the virus to a few laboratories worldwide.

Andreas von Bubnoff

See Editorial, page 130

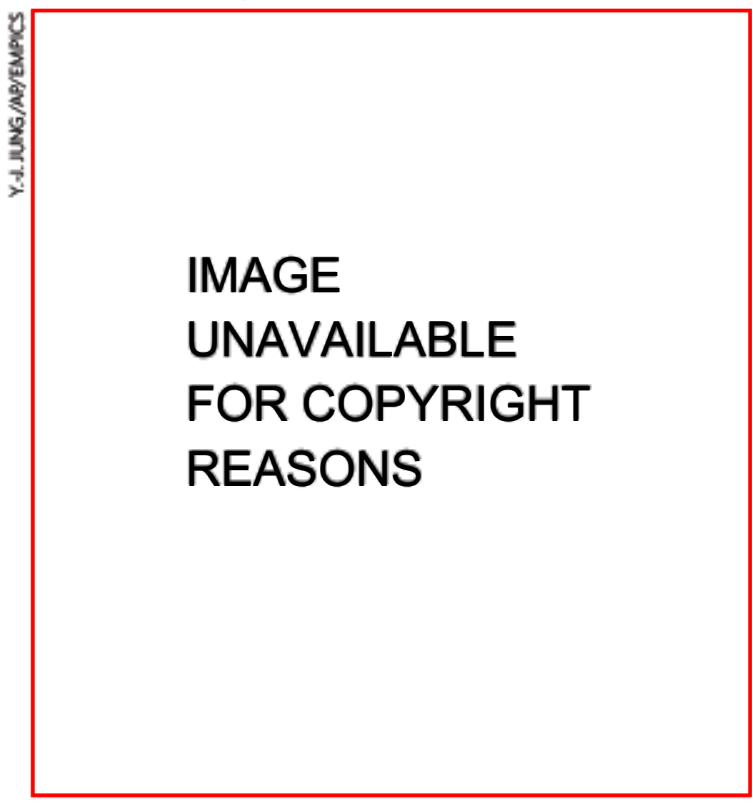

Woo Suk Hwang says Asia has huge potential in cloning. which the sperm is often held (N. Van Thuan et al. Biol Reprod. 72, 444-450; 2005). Thuan, who is Vietnamese, says that the technique could help his country's scientists to transport samples and run studies involving mice sperm, without taking up scarce refrigerator space.

Despite a lack of resources, Thailand and Vietnam host country for the first Asian Reproductive Biotechnology meeting are hoping for a bright future. The Thailand Research Fund willstart a US\$50-million grant programme for stem-cell research in 2006, and earlier this year the Vietnamese government promised to boost research spending to $2 \%$ of its gross domestic product (GDP).

This will more thandouble current investment, and a goodchunk is expected togo to reproductive biology. Two stem-cell scientists, Nguyen Mong Hung at the Hanoi University of Science, and Bui Xuan Nguyen at the Vietnamese Academy of Science and Technology in Hanoi, will be getting US $\$ 500,000$ a year to head centres of excellence in the field.

Hwang says that there is particular scope for collaboration in the cloning and derivation of monkey stem cells todevelop models for hum an disease. He expects that a collaboration of scientists from South Korea, Japan, China and other Asian countries with access to primate populations will form a significantpart of his recently formed network for exchanging stem-cell lines and cloning technology (see Nature 437, 1077; 2005). David Cyranoski 